International Journal of Economics, Business and Accounting Research (IJEBAR)

Peer Reviewed - International Journal

Vol-4, Issue-2, 2020 (IJEBAR)

E-ISSN: 2614-1280 P-ISSN 2622-4771

https://jurnal.stie-aas.ac.id/index.php/IJEBAR

\title{
THE ROLE OF LEADERSHIP STYLES IN ENCOURAGING AND IMPROVING TEAM PERFORMANCE IN ONE OF THE BIGGEST OIL \& GAS GROUP OF COMPANIES IN ABU DHABI, UAE
}

\author{
Anas Abudaqa, ${ }^{1)}$ Mohd Faiz, ${ }^{2)}$ Norziani Dahalan, ${ }^{3)}$ Hasan AlMujaini ${ }^{4)}$ \\ School of Distance Education, Universiti Sains Malaysia, Penang, Malaysia ${ }^{1,2,3,4}$ \\ E-mail: aabudaqal@gmail.com
}

\begin{abstract}
The aim of the current study is to examine the impact of leadership styles such as transformational leadership, transactional leadership and participative leadership on the team performance of one of the biggest oil \& gas group of companies in UAE. The goal also includes the moderating role of perceived organizational culture on the links of transformational leadership and team performance, transactional leadership team performance, participative leadership, and team performance. The employees who have at least one immediate boss and currently working in one of the biggest oil \& gas group of companies are the respondent and data were gathered by using questionnaires and it was analyzed by using Smart-PLS. The results indicated that transformational leadership, transactional leadership, and participate leadership have positive nexus with team performance. The results also indicated that perceived organizational culture has positively moderates among the nexus of transformational leadership and team performance, transactional leadership team performance, participative leadership, and team performance. The regulators of this group of companies will be the foremost users who want to formulate policies regarding the leadership style that improves team performance.
\end{abstract}

Keywords: $\quad$ Transformational Leadership, Transactional Leadership, Participate Leadership, Team Performance, Perceived Organizational Culture

\section{Introduction}

The performance of an employee is an important key for team performance effectiveness. The best performance of times often the basic result which an organization wants to achieve. Thus, this research investigated the consequences of leadership attitude on the performance of workers in one of the biggest oil \& gas group of companies in Abu Dhabi, UAE, via the arbitrary role of participation. Furthermore, many studies showed that there was a moderation consequence in the correlation between the performance of the team and the styles of leadership (Shahin, Naftchali, \& Pool, 2014). It was suggested that managers having better qualities of leadership should be selected in the oil and gas company within the UAE for enhancing organizational participation. Due to this, the worker's performance can be more developed, and the overall performance of an organization can more important and positive. In Abu Dhabi, it was the National Oil Company who in 1953 discovers oil in MBO (Murban Bab Oil Filed). The company took about three years for 112-kilometer pipeline creation. Later on, it further discovered some other oil fields like BAQ, etc. The company revenue continues to increase in the year 1971 and results in the formation of a new venture Abu Dhabi National Company by the late Sheikh Zayed bin Sultan.

The 2030 strategy of the company is to: "Transform the way we maximize value from every barrel, to deliver the greatest possible return to Abu Dhabi as we help meet the world's growing demand for energy". The national oil company of Abu Dhabi is a company whose influence and contributions to the United Arab Emirates' national economy cannot be ignored. There is total of 17 subclasses in the gas and 
International Journal of Economics, Business and Accounting Research (IJEBAR)

Peer Reviewed - International Journal

Vol-4, Issue-2, 2020 (IJEBAR)

E-ISSN: 2614-1280 P-ISSN 2622-4771

https://jurnal.stie-aas.ac.id/index.php/IJEBAR

oil and as well as the industry of petrol chemical and which also includes the logistics and transport services of gas and oil. These types of variety have made sure that the company has still carried on the wealth for the nation and in the area of employment. Same like, the United Arab Emirates reports that 4.3 percent of the middle east regional oil and up to 10 percent of the gas in the universe. Moreover, the consequences of leadership attitude towards team performance and leadership have a lot of influence on the success of the organization. Only, little leaders understand the significance of how important their behavior of leadership is to team performance.

In the past few years, the involvement of the team has been researched vastly, and extra attention has been given to the correlation between the culture of the organization and few variables like effectiveness, productivity, organizational framework, efficiency and style of leadership (Keegan \& Den Hartog, 2004). However, there has been no research in regard to team performance of workers specifically in sectors of oil and gas. In addition, the performance of the team on the overall job area performance is considerable because all the members within a team contribute individually towards the performance of the team by giving their efforts in various ways and as well as giving suggestions which are very useful to the team performance (Sosik \& Godshalk, 2000). Team performance has more positive effects and less negative effects on the team performance due to its nature of upholding the conflicts within the teams and the communication leadership styles. Furthermore, team performance is more positively affected due to team performance which gives cohesiveness opportunity to the team members and letting them work more effectively (Li, Meng, Wang, \& Zhou, 2008).

\subsection{Research Objectives}

1. To examine the effect of transformational leadership on team performance.

2. To investigate the effect of transitional leadership on team performance.

3. To determine the effect of Participative leadership on team performance.

4. To determine the moderating effect of POC on the relationship between leadership styles and team performance.

\subsection{Research Aim}

The prime aims of this investigation are:

- Theory testing with a new data set and new model.

- Test the moderation effect of perceived organizational climate on the relationship between leadership styles and team performance.

- Provide a new insight into a firm's leadership to have better decision making for enhancement of team performance.

\section{Literature Review}

Basically according to the theories relevant to the style of transformational leadership tells us that the performance of workers and their commitments towards leading organizational innovations are included indirect effects. Transformational leadership is considered as the most motivating approach among various leadership approaches (Clarke, 2013). Moreover, it is also debated that the leaders of transformation need to consider four different types of factors or at least one of the factors should be taken into consideration. These all four factors have a considerable impact on the performance of the leaders. Furthermore, for obtaining the objectives which are decided and finalized by the transformational leaders there is a strong bond that is associated and is helpful to formulate the eagerness and aspiration in the followers.

\subsection{Transformational Leadership}


International Journal of Economics, Business and Accounting Research (IJEBAR)

Peer Reviewed - International Journal

Vol-4, Issue-2, 2020 (IJEBAR)

E-ISSN: 2614-1280 P-ISSN 2622-4771

https://jurnal.stie-aas.ac.id/index.php/IJEBAR

A condition is featured by idealized impact by doing right and suitable activities bracing their belief in their followers instead of asking them to do better performance solely. Whenever they conduct correct things they become ideals. For example, when leaders have positive features like high ethics and focus on a high order, then there exists an attachment that is emotional between the leader and the follower (Aldoory \& Toth, 2004). Moreover, due to this kind of relationship trust and confidence is buildup.

Those leaders who are involved in inspirational motivation enhance and give a platform to all their workers for encouraging them in achieving an unexpected performance extent (Arnold, Turner, Barling, Kelloway, \& McKee, 2007). To formulate and show a specific innovation is the main concern of this type of leadership. In addition, the turnover of the organization is enhanced due to the motivation of these leaders. It identifies various solutions regarding existing issues in different and unique ways. All the questions of the employees are not answered by the intellectual stimulation normally. Moreover, intellectual stimulation deeply examines the issues of followers and as well as provide solutions to them (Piccolo \& Colquitt, 2006). In individual consideration, all of the workers are appreciated and their achievements are celebrated. In the area of organizational attitude, leadership is considered as a central subject (Dvir, Eden, Avolio, \& Shamir, 2002). Furthermore, the leaders of our great must not only encourage the energy of subordinates to enhance competence but they need to accomplish their requirements in obtaining the aims of the organization.

\subsection{Transactional Leadership}

In accordance with a study on leadership has been defined as benefit and cost interchange practices. The theories which are based on the transactional leadership are set up on the concept of the relations of leader-followers on the ground on the continuous interchange between the followers and their leaders (Barling, Weber, \& Kelloway, 1996). Moreover, this kind of leadership is considered by attitudes that underline the interchanging quality between the managers and the followers.

In addition, the leadership of transactions is actually based on the two methods and continuous interchange between the leaders and juniors (Bycio, Hackett, \& Allen, 1995). Therefore, these leaders show effectiveness for the juniors thus; these leaders develop the talent of employees for the long term. Furthermore, transactional leadership plans to increase agreement between the leaders and followers. The exchange that takes place in this type of leadership is when the necessary resources are provided by the leaders and then later on the followers make his command and publicly show it.

\subsection{Participative Leadership}

Participative leadership means a combined making decision and as well as shared impacts by a manager and her of his workers. This type of decision making suggests various benefits to workers and to the organization itself by developing the confidence level of workers, quality of work and also enhancing decision quality (Kuhnert \& Lewis, 1987). Moreover, the leaders of participative include their juniors during the process of decision making for imposing and formulating decisions and they also take opinion from them. These opinions influence internal and external strategies. In addition, for organizing better linkage between the leaders and the workers in an institution, the relations of human and resources of participative decision making are necessary which are based on three crucial modules; efficacious communication, enhancement of worker and harmonic relations of employment, these types of elements emphasis the communal communication and equality of power between workers and leaders (Howell \& Avolio, 1993).

In addition, in human relations point of view participation is a mechanism by which workers can know about their performance and ideas regarding changes that are made in decisions as it is minimizing interaction and resistance of the workers. Senior managers also prefer participation in giving guidance to 
International Journal of Economics, Business and Accounting Research (IJEBAR)

Peer Reviewed - International Journal

Vol-4, Issue-2, 2020 (IJEBAR)

E-ISSN: 2614-1280 P-ISSN 2622-4771

https://jurnal.stie-aas.ac.id/index.php/IJEBAR

the workers to have belief and feel importance regarding their contribution in the process of decision making and as well as motivating and encouraging them to perform much better (Judge \& Piccolo, 2004). Furthermore, it may also develop workers' similar culture, responsibility, etc. and also enhance the workers' opportunities in achieving updated information and comprehension.

\subsection{Perceived Organizational Climate}

The climate of any organization often throws a strong impact on all the sections of an organization. Organizational climate tells us about the attributes of the team performance, whereas the perceived organizational climate seems ambivalent because an individual cannot be assured that this refers to an organizational attribute or the perceiving individuals (Taştan \& Güçel, 2014). Moreover, if it alludes to the organization, then perceived organizational climate measures should be expanded in regard to the perception accuracy. But if it alludes to the individual, then the perceived climate organization may be another name for satisfaction or job or behavior or workers. Perceived organizational climate not only having an impact on leadership but it also affects the performance of the team (Gould-Williams, 2007).

\subsection{Team Performance}

The performance of the team has been labeled in the literature of the team as a usual structure that includes resources input, altogether efforts during the process and particular indicators of performance on results. The particular indicators of performance and the some of the resources available may change from team to team, for the reasons we show team performance as the performance of process type (Miceli $\&$ Near, 1985). Furthermore, the performance of the team as a process building is not a new wonder, whereas the performance which is based on the team process may include, between others, an effort that is given by all of the participants or the interpersonal correlation quality which is known as teamwork emphasizing on the performance as against a task work emphasis.

In addition, referring a performance of the team as a process of teamwork build allows the theoretical connections which are related to processes that are based interpersonally and are probably available in all teams like cohesion, management conflicts, and communication between team members (Köllen, 2016). So, due to this, the interpersonal correlation quality is represented by the performance of the team or we can say that the performance of the team is represented as a process-based teamwork build.

Cohesion shows the level to which team members are encouraged to stay on the team. The teams with a high level of cohesion tend to have more involvement in the tasks performed in the team, maximum extents of coordination between the members of the team while performing the team activities and minimum absenteeism (Daniel, 1985). Moreover, the cohesion in the team has been focused as a critical encouraging factor that impacts the performance of the team in the previous study that has been conducted actually. According to these previous connections which exist between team performance and cohesion, the below proposition is drawn:

Efficacious performance of the team is due to these communication-based factors; feedback, prompt, suggestions and enhancing listening. For completing the regular activities of the team and obtaining the objectives easily the easy and open communication within a team is very important (Peterson, 1975). On the base of previous actual and conceptual connections between the performance of team and communication and efficaciousness, the below mention proposition is drawn: Management conflicts always arise whenever there is a disagreement between the team members of the team or between two various teams. These kinds of conflicts become harmful for the members and as well as for teams also in regard to thinking and making better decisions (Shahin et al., 2014). Although, all the conflicts may not 
International Journal of Economics, Business and Accounting Research (IJEBAR)

Peer Reviewed - International Journal

Vol-4, Issue-2, 2020 (IJEBAR)

E-ISSN: 2614-1280 P-ISSN 2622-4771

https://jurnal.stie-aas.ac.id/index.php/IJEBAR

be that harmful to the teams they can be ignorable. Moreover, the conflicts of the team depend that how the team members manage them and the ways they adapt to control and solve the issues. Furthermore, the conflicts which are positive in nature like competition and collaboration positively influence team performance (Taştan \& Güçel, 2014).

\subsection{Research Hypotheses}

1. There is an association between transformational leadership and team performance.

2. There is an association between transactional leadership and team performance.

3. There is an association between participative leadership and team performance.

4. Perceived organizational climate moderates the relationship between transformational leadership style and team performance.

5. Perceived organizational climate moderates the relationship between transactional leadership style and team performance.

6. Perceived organizational climate moderates the relationship between participative leadership style and team performance.

\section{Research Methods}

This study follows the quantitative methods of data collection. The employees who have at least one immediate boss and currently working in one of the biggest oil \& gas group of companies are the respondent and data were gathered by using questionnaires and it was analyzed by using Smart-PLS.

\subsection{Research Population}

The target population of the present study was the whole oil refining companies that are operating in the territory of Abu Dhabi because the economy of the UAE is majorly based on the oil production and income that are generated from the oil processing.

\subsection{Sample Frame and Sampling Techniques}

As the target population is the oil refining companies of Abu Dhabi, the current study selected one of the biggest oil \& gas group of companies on the basis of purposive sampling because the purpose of this study is to target the largest oil refining company of Abu Dhabi. More than 75000 employees are currently working and the respondents were selected on the basis of simple random sampling.

\subsection{Sample Size}

The selected company has more than 75000 employees and around more than 72000 employees have an immediate boss and are the respondents of the study. According to the table of sample size developed by Krejcie and Morgan (1970), 382 are the sample size if the population is 75000. Thus, around 390 respondents were taken by the study for data collection.

\subsection{Data Collection Procedure}

Prior to the data collection, it is required to get approval from the relevant authorities and for this reason, a request letter sends to the relevant authorities for gathering the data along with the purpose letter that tells the aim of the study to the authorities. After getting the approval, a total of 390 questionnaires were sent but only 291 questionnaires were received that were used for the analysis that represents 74.62 percent response rate.

\subsection{Research Model}

The existing study developed the six hypotheses out of the three are direct hypotheses among the predictors and dependent variable, while three are indirect hypothesis related to the moderating role of perceived organizational climate among the predictors and dependent variable. Figure 1 showed the research model of the current study. 
International Journal of Economics, Business and Accounting Research (IJEBAR)

Peer Reviewed - International Journal

Vol-4, Issue-2, 2020 (IJEBAR)

E-ISSN: 2614-1280 P-ISSN 2622-4771

https://jurnal.stie-aas.ac.id/index.php/IJEBAR

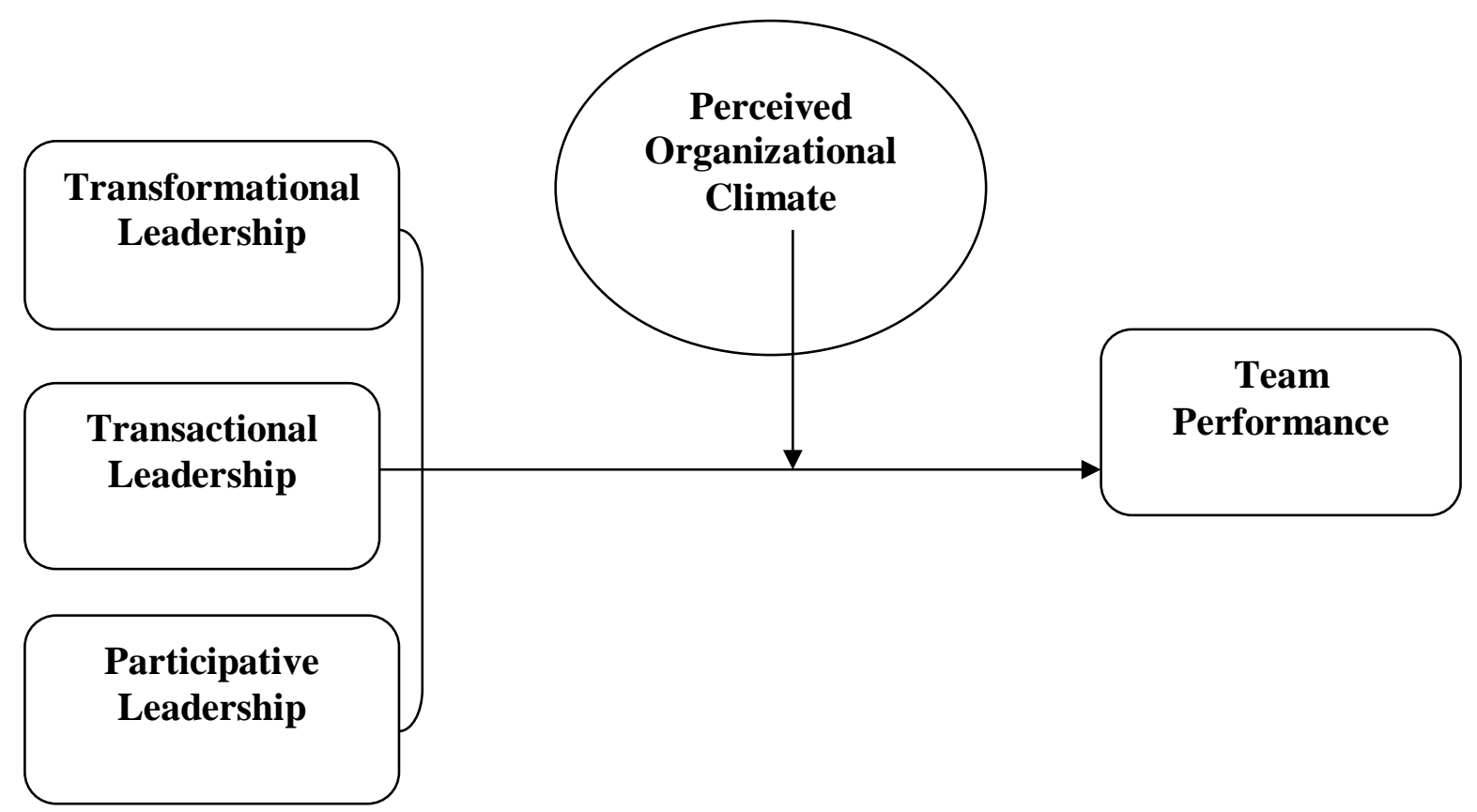

Figure 1: Theoretical Framework

\section{Data Analysis}

The data analysis section firstly shows the convergent validity about the correlation among the items and the figures such as loadings more than 0.40, AVE more than 0.50, Alpha and CR values are larger than 0.70 show that valid convergent validity because high correlation among the items and these figures are shown in Table 1.

Table 1: Convergent Validity

\begin{tabular}{llcccc}
\hline Constructs & Items & Loadings & Alpha & CR & AVE \\
\hline Perceived Organizational Culture & POC1 & 0.863 & 0.869 & 0.838 & 0.512 \\
& POC2 & 0.537 & & & \\
& POC3 & 0.609 & & & \\
POC4 & 0.636 & & & \\
POC5 & 0.538 & & & \\
POC6 & 0.259 & & & \\
Participative Leadership & POC7 & 0.858 & & & \\
& POC8 & 0.628 & & & \\
& PTL1 & 0.865 & 0.865 & 0.904 & \\
& PTL2 & 0.596 & & & \\
& PTL3 & 0.873 & & & \\
PTL4 & 0.865 & & & \\
& PTL5 & 0.818 & & & \\
\hline
\end{tabular}


International Journal of Economics, Business and Accounting Research (IJEBAR)

Peer Reviewed - International Journal

Vol-4, Issue-2, 2020 (IJEBAR)

E-ISSN: 2614-1280 P-ISSN 2622-4771

https://jurnal.stie-aas.ac.id/index.php/IJEBAR

\begin{tabular}{|c|c|c|c|c|c|}
\hline \multirow[t]{20}{*}{ Transformational Leadership } & TFL1 & 0.844 & \multirow[t]{20}{*}{0.956} & \multirow[t]{20}{*}{0.961} & \multirow[t]{20}{*}{0.558} \\
\hline & TFL10 & 0.830 & & & \\
\hline & TFL11 & 0.814 & & & \\
\hline & TFL12 & 0.809 & & & \\
\hline & TFL13 & 0.814 & & & \\
\hline & TFL14 & 0.768 & & & \\
\hline & TFL15 & 0.436 & & & \\
\hline & TFL16 & 0.481 & & & \\
\hline & TFL17 & 0.494 & & & \\
\hline & TFL18 & 0.488 & & & \\
\hline & TFL19 & 0.848 & & & \\
\hline & TFL2 & 0.826 & & & \\
\hline & TFL20 & 0.839 & & & \\
\hline & TFL3 & 0.830 & & & \\
\hline & TFL4 & 0.817 & & & \\
\hline & TFL5 & 0.680 & & & \\
\hline & TFL6 & 0.757 & & & \\
\hline & TFL7 & 0.734 & & & \\
\hline & TFL8 & 0.815 & & & \\
\hline & TFL9 & 0.771 & & & \\
\hline \multirow[t]{6}{*}{ Team Performance } & $\mathrm{TP} 1$ & 0.578 & \multirow[t]{6}{*}{0.844} & \multirow[t]{6}{*}{0.887} & \multirow[t]{6}{*}{0.570} \\
\hline & $\mathrm{TP} 2$ & 0.781 & & & \\
\hline & TP3 & 0.647 & & & \\
\hline & TP4 & 0.815 & & & \\
\hline & TP5 & 0.838 & & & \\
\hline & TP6 & 0.831 & & & \\
\hline \multirow[t]{10}{*}{ Transactional Leadership } & TSL1 & 0.414 & \multirow[t]{10}{*}{0.950} & \multirow[t]{10}{*}{0.960} & \multirow[t]{10}{*}{0.721} \\
\hline & TSL11 & 0.941 & & & \\
\hline & TSL12 & 0.919 & & & \\
\hline & TSL2 & 0.916 & & & \\
\hline & TSL3 & 0.931 & & & \\
\hline & TSL4 & 0.411 & & & \\
\hline & TSL5 & 0.925 & & & \\
\hline & TSL6 & 0.939 & & & \\
\hline & TSL7 & 0.920 & & & \\
\hline & TSL9 & 0.921 & & & \\
\hline
\end{tabular}

The data analysis section secondly shows the discriminant validity of the correlation among the constructs and the figures such as the ratio of Heterotrait Monotrait (HTMT) are less than 0.90 and show valid 
International Journal of Economics, Business and Accounting Research (IJEBAR)

Peer Reviewed - International Journal

Vol-4, Issue-2, 2020 (IJEBAR)

E-ISSN: 2614-1280 P-ISSN 2622-4771

https://jurnal.stie-aas.ac.id/index.php/IJEBAR

discriminant validity because no high correlation among the constructs and these figures are shown in Table 2.

Table 2: Heterotrait Monotrait Ratio

\begin{tabular}{llllll}
\hline & POC & PTL & TFL & TP & TSL \\
\hline POC & & & & & \\
PTL & 0.269 & & & & \\
TFL & 0.310 & 0.614 & & & \\
TP & 0.284 & 0.451 & 0.556 & 0.498 & \\
TSL & 0.625 & 0.557 & 0.594 & 0.59 \\
\hline
\end{tabular}

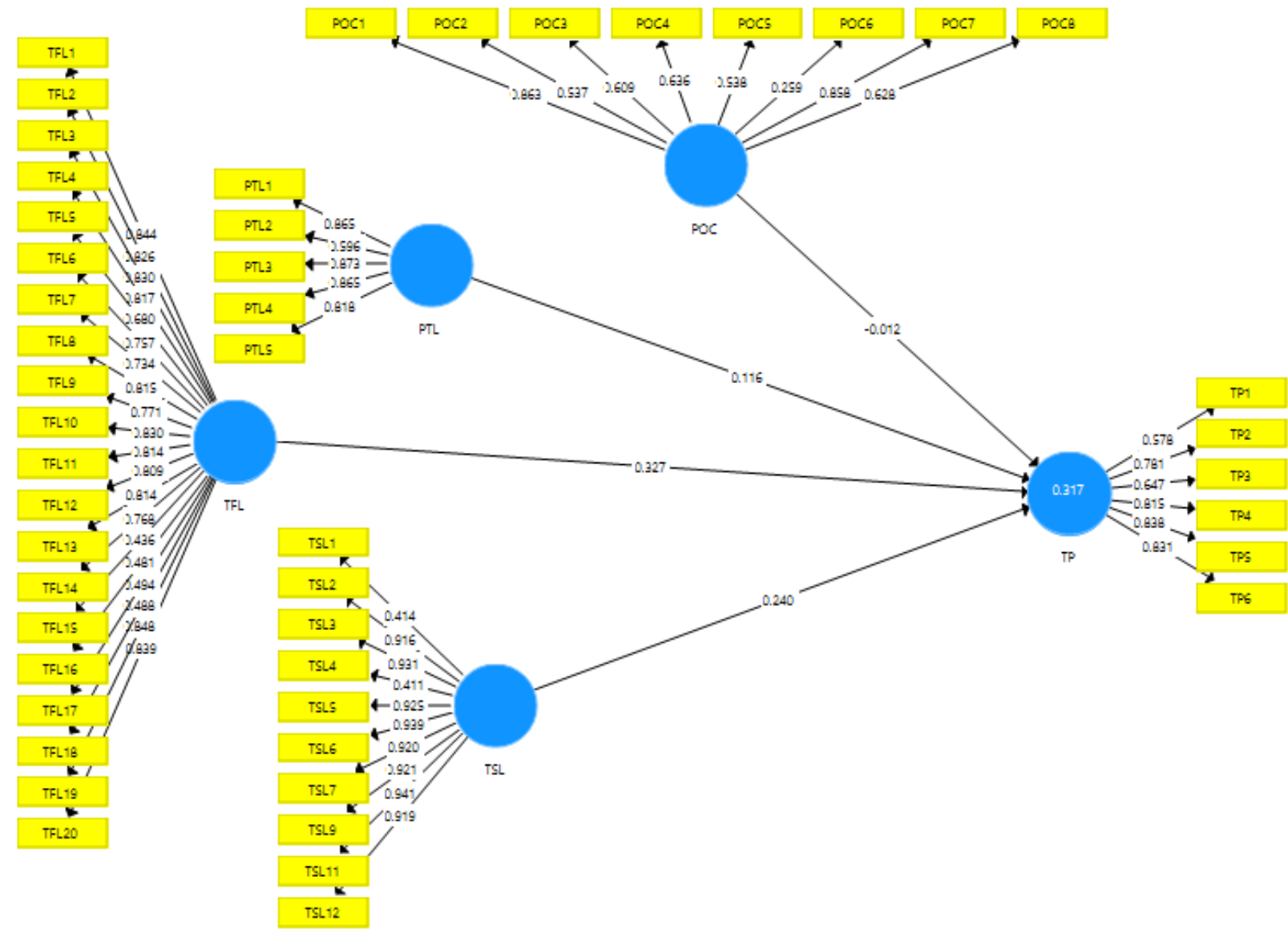

Figure 2: Measurement Model Assessment

The path analysis shows that all the leadership style such as transformative leadership, transaction leadership, and participative leadership have positive nexus with team performance and accept $\mathrm{H} 1, \mathrm{H} 2$, and H3. The perceived organizational climate has positive moderation among the links of transformational leadership and team performance, transactional leadership team performance, participative leadership, and team performance and accepts H4, H5, and H6. These figures are shown in Table 3, Figure 3, Figure 4, Figure 5 and Figure 6 given below: 
International Journal of Economics, Business and Accounting Research (IJEBAR)

Peer Reviewed - International Journal

Vol-4, Issue-2, 2020 (IJEBAR)

E-ISSN: 2614-1280 P-ISSN 2622-4771

https://jurnal.stie-aas.ac.id/index.php/IJEBAR

Table 3: Path Analysis

\begin{tabular}{lcccccc}
\hline & Beta & S.D. & t-values & p-values & L.L. & U.L. \\
\hline PTL -> TP & 0.150 & 0.075 & 1.998 & 0.024 & 0.035 & 0.275 \\
PTL*POC -> TP & 0.141 & 0.061 & 2.309 & 0.012 & 0.001 & 0.210 \\
TFL -> TP & 0.287 & 0.070 & 4.110 & 0.000 & 0.201 & 0.387 \\
TFL*POC -> TP & -0.256 & 0.059 & 4.340 & 0.000 & -0.349 & -0.156 \\
TSL -> TP & 0.295 & 0.166 & 1.776 & 0.039 & 0.063 & 0.468 \\
TSL*POC -> TP & 0.163 & 0.078 & 2.095 & 0.019 & 0.036 & 0.284 \\
\hline
\end{tabular}

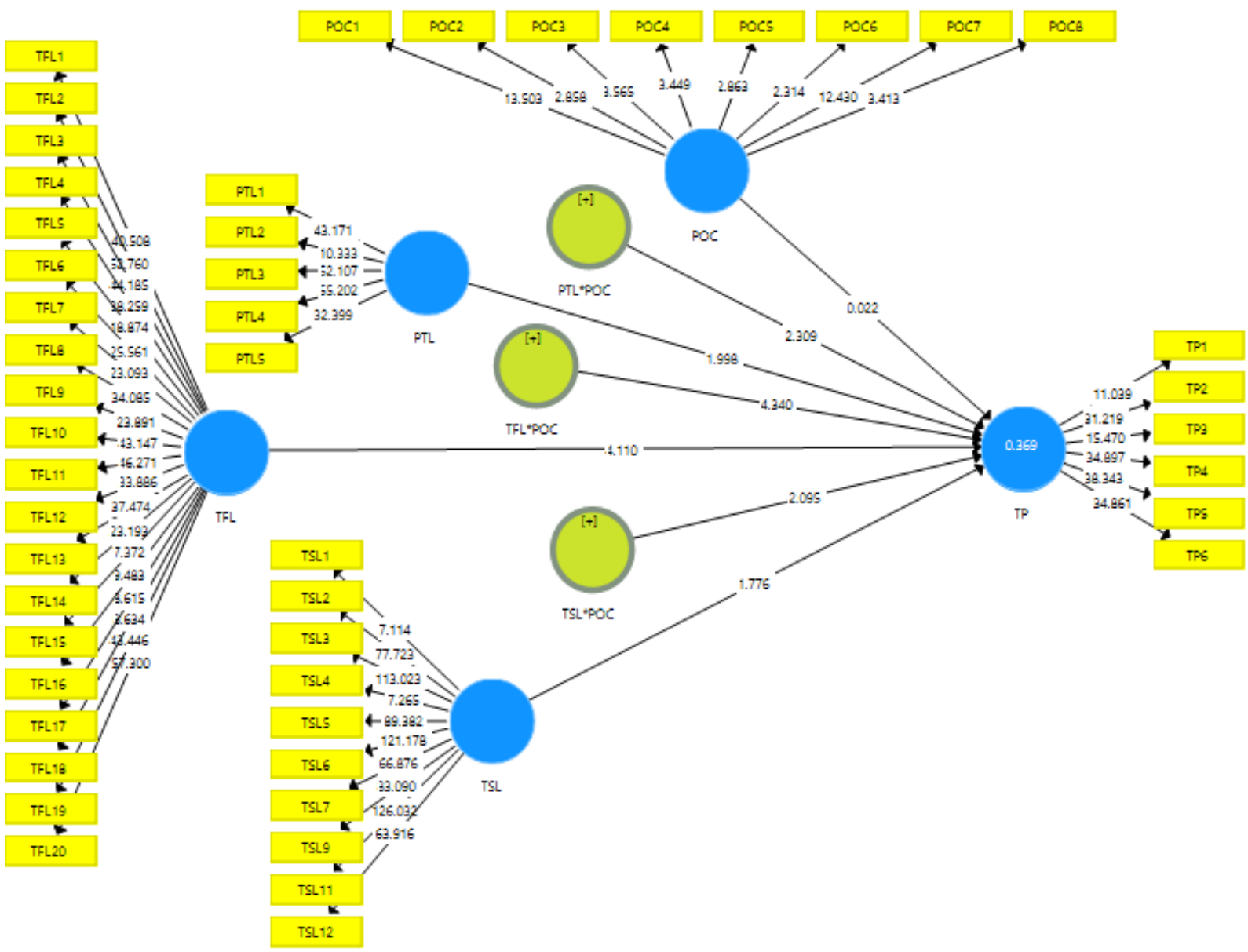

Figure 3: Structural Model Assessment 
International Journal of Economics, Business and Accounting Research (IJEBAR)

Peer Reviewed - International Journal

Vol-4, Issue-2, 2020 (IJEBAR)

E-ISSN: 2614-1280 P-ISSN 2622-4771

https://jurnal.stie-aas.ac.id/index.php/IJEBAR

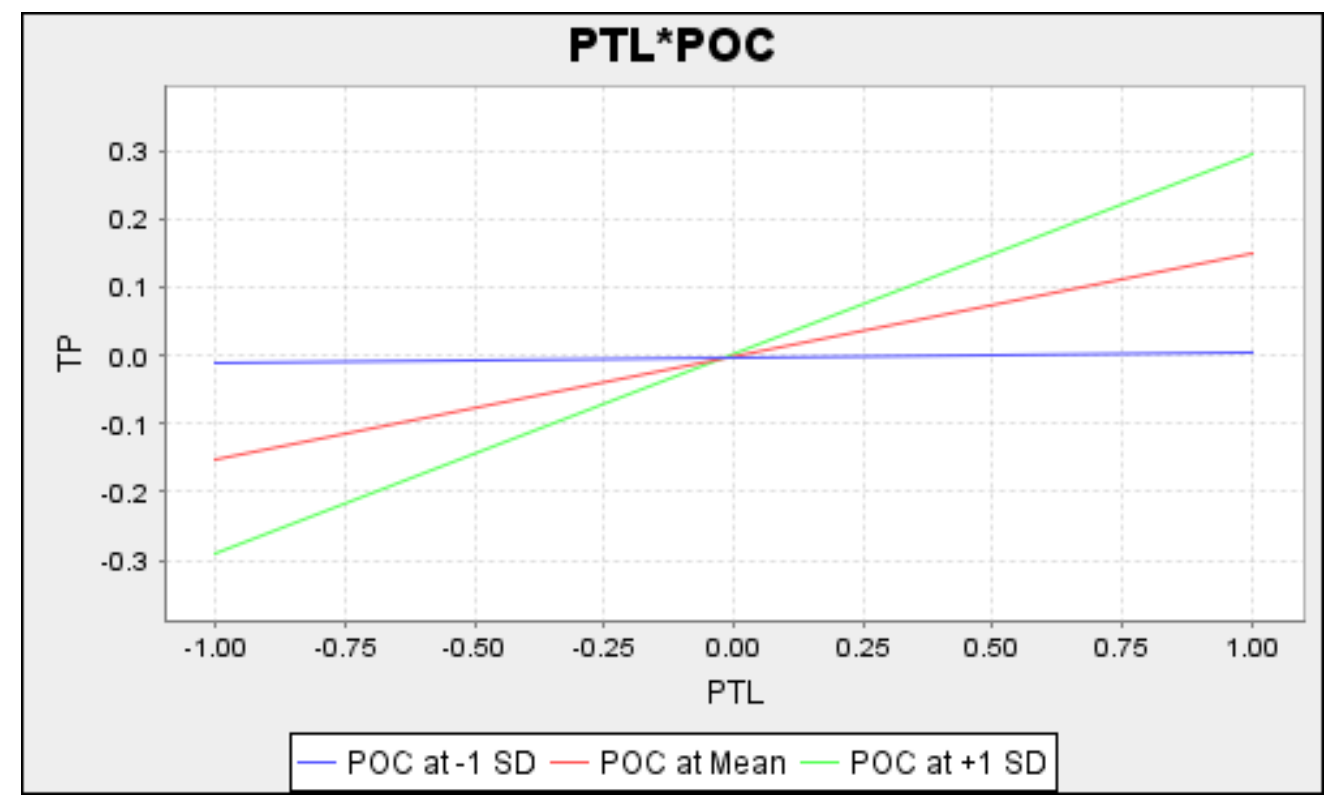

Figure 4: PTL*POC

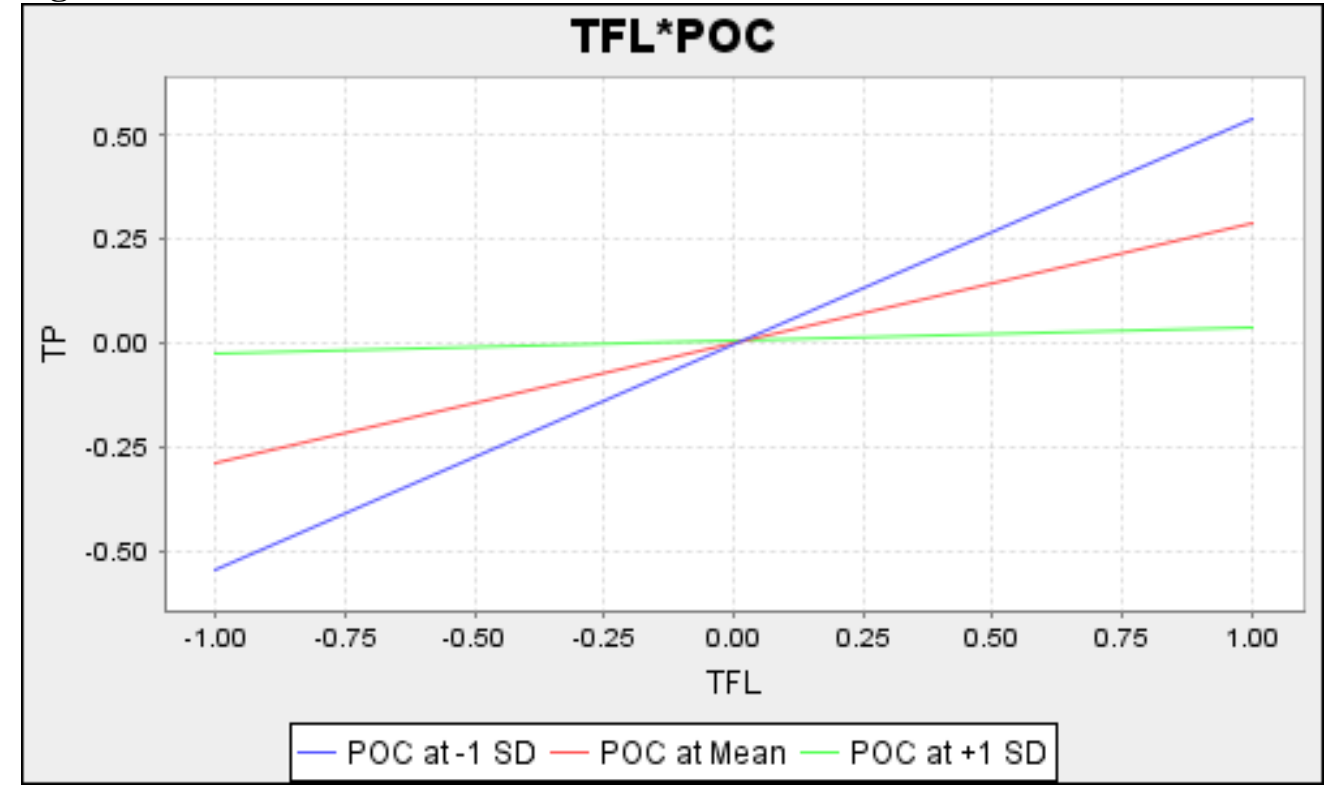

Figure 5: TFL*POC 
International Journal of Economics, Business and Accounting Research (IJEBAR)

Peer Reviewed - International Journal

Vol-4, Issue-2, 2020 (IJEBAR)

E-ISSN: 2614-1280 P-ISSN 2622-4771

https://jurnal.stie-aas.ac.id/index.php/IJEBAR

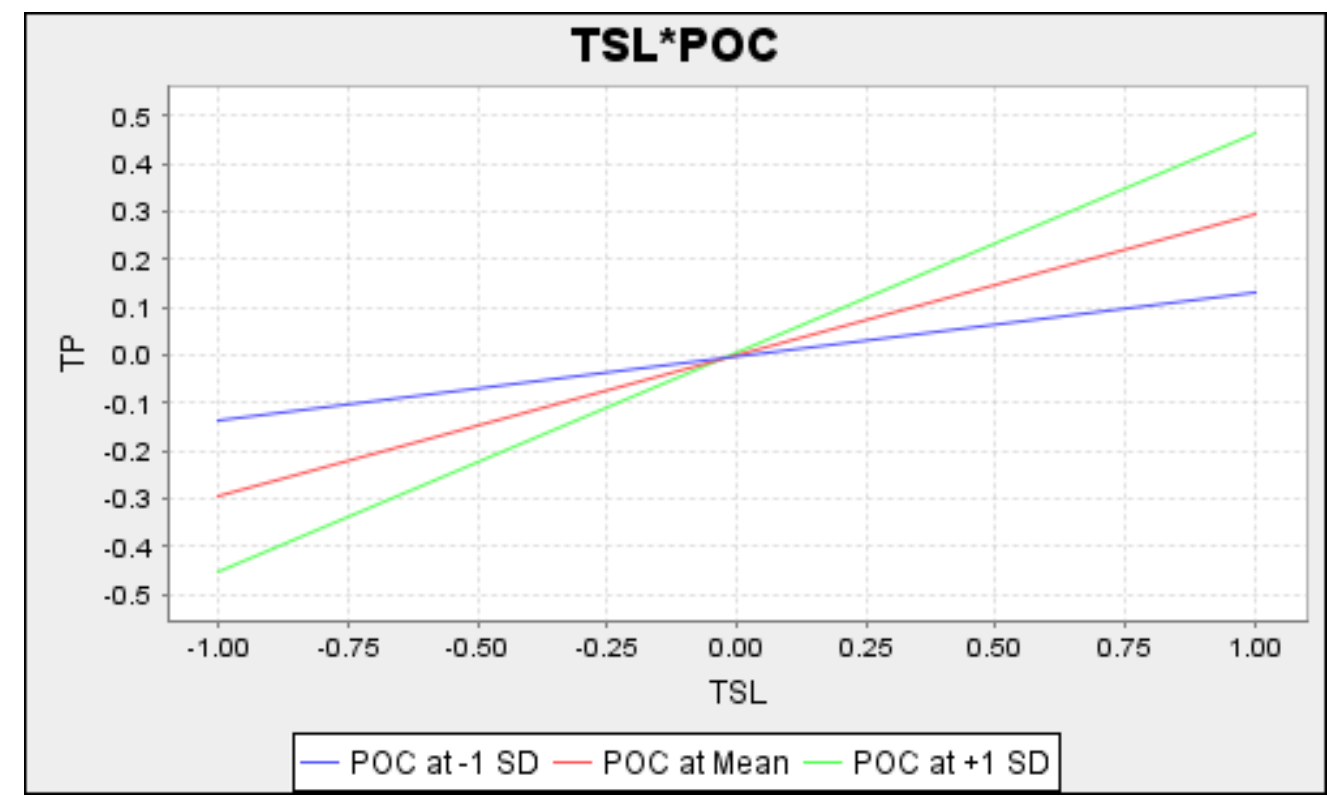

Figure 6: TSL*POC

\section{Discussions}

The results indicated that transformational leadership, transactional leadership, and participate leadership have positive nexus with team performance. The results also indicated that perceived organizational culture has positively moderates among the nexus of transformational leadership and team performance, transactional leadership team performance, participative leadership, and team performance. The regulators of the selected company will be the foremost users who want to formulate policies regarding the leadership style that improves team performance. These findings are similar to the past studies output such as Gipson, Pfaff, Mendelsohn, Catenacci, and Burke (2017) and Nguyen, Mia, Winata, and Chong (2017) who also found that transformational leadership and participative leadership have positive nexus with the team performance. Moreover, the study of Törner, Pousette, Larsman, and Hemlin (2017) also found that supportive organizational climate positive influence of the leadership style that improve the team performance of the firm and matched with current study findings.

\subsection{Recommendations}

This study recommended to the policymakers of the selected company that they should increase their emphasis on the leadership styles along with the climate of the organization that supports the financial performance of the organization. In addition, the regulators of the selected company will be the foremost users who want to formulate policies regarding the leadership style that improves team performance. This study also recommended to the new researcher that they should add the mediation aspect in this study while exploring this area in the future.

\subsection{Conclusion}

Finally, this study concluded that one of the biggest oil \& gas group of companies in Abu Dhabi, UAE have a strong leadership style that motivates the employees through incentives and morally grooming activities that is the reason of the high performance of the company among the largest organization in Abu Dhabi. The study also concluded that the climate of the organization is very supportive that enhance the leadership style impact on the team performance in the organization. 
International Journal of Economics, Business and Accounting Research (IJEBAR)

Peer Reviewed - International Journal

Vol-4, Issue-2, 2020 (IJEBAR)

E-ISSN: 2614-1280 P-ISSN 2622-4771

https://jurnal.stie-aas.ac.id/index.php/IJEBAR

\section{References}

Abdelmoumen, B. (2018). The influence of leadership styles on job performance in telecommunication company of Algeria (OTA). Universiti Utara Malaysia.

Aldoory, L., \& Toth, E. (2004). Leadership and gender in public relations: Perceived effectiveness of transformational and transactional leadership styles. Journal of Public Relations Research, 16(2), 157-183. doi: https://doi.org/10.1207/s1532754xjprr1602_2

Arnold, K. A., Turner, N., Barling, J., Kelloway, E. K., \& McKee, M. C. (2007). Transformational leadership and psychological well-being: the mediating role of meaningful work. Journal of occupational health psychology, 12(3), 193. doi: https://psycnet.apa.org/doi/10.1037/10768998.12.3.193

Avolio, B. J. (1999). Full leadership development: Building the vital forces in organizations: Sage.

Balozi, M. A. (2017). Examining individual, job and perceived organizational climate factors in relation to the knowledge sharing behavior. Universiti Utara Malaysia.

Barling, J., Weber, T., \& Kelloway, E. K. (1996). Effects of transformational leadership training on attitudinal and financial outcomes: A field experiment. Journal of Applied psychology, 81(6), 827. doi: https://psycnet.apa.org/doi/10.1037/0021-9010.81.6.827

Bass, B. M., \& Avolio, B. J. (1997). Concepts of leadership. Leadership: Understanding the dynamics of power and influence in organizations, 3-22.

Bycio, P., Hackett, R. D., \& Allen, J. S. (1995). Further assessments of Bass's (1985) conceptualization of transactional and transformational leadership. Journal of Applied psychology, 80(4), 468. doi: https://psycnet.apa.org/doi/10.1037/0021-9010.80.4.468

Clarke, S. (2013). Safety leadership: A meta-analytic review of transformational and transactional leadership styles as antecedents of safety behaviours. Journal of occupational and organizational psychology, 86(1), 22-49. doi: https://doi.org/10.1111/j.2044-8325.2012.02064.x

Daniel, T. L. (1985). Managerial behaviors: Their relationship to perceived organizational climate in a high-technology company. Group \& Organization Studies, 10(4), 413-428. doi: https://doi.org/10.1177\%2F105960118501000404

Dvir, T., Eden, D., Avolio, B. J., \& Shamir, B. (2002). Impact of transformational leadership on follower development and performance: A field experiment. Academy of management Journal, 45(4), 735744. doi: https://doi.org/10.5465/3069307

Gipson, A. N., Pfaff, D. L., Mendelsohn, D. B., Catenacci, L. T., \& Burke, W. W. (2017). Women and leadership: Selection, development, leadership style, and performance. The Journal of Applied Behavioral Science, 53(1), 32-65.

Gould-Williams, J. (2007). HR practices, organizational climate and employee outcomes: evaluating social exchange relationships in local government. The International Journal of Human Resource Management, 18(9), 1627-1647. doi: https://doi.org/10.1080/09585190701570700

Howell, J. M., \& Avolio, B. J. (1993). Transformational leadership, transactional leadership, locus of control, and support for innovation: Key predictors of consolidated-business-unit performance. Journal of Applied psychology, 78(6), 891. doi: https://psycnet.apa.org/doi/10.1037/00219010.78.6.891

Judge, T. A., \& Piccolo, R. F. (2004). Transformational and transactional leadership: a meta-analytic test of their relative validity. Journal of Applied psychology, 89(5), 755. doi: https://psycnet.apa.org/doi/10.1037/0021-9010.89.5.755

Keegan, A. E., \& Den Hartog, D. N. (2004). Transformational leadership in a project-based environment: a comparative study of the leadership styles of project managers and line managers. International journal of project management, 22(8), 609-617. doi: https://doi.org/10.1016/j.ijproman.2004.05.005 
International Journal of Economics, Business and Accounting Research (IJEBAR)

Peer Reviewed - International Journal

Vol-4, Issue-2, 2020 (IJEBAR)

E-ISSN: 2614-1280 P-ISSN 2622-4771

https://jurnal.stie-aas.ac.id/index.php/IJEBAR

Köllen, T. (2016). Lessening the difference is more-the relationship between diversity management and the perceived organizational climate for gay men and lesbians. The International Journal of Human Resource Management, 27(17), 1967-1996. doi: https://doi.org/10.1080/09585192.2015.1088883

Krejcie, R. V., \& Morgan, D. W. (1970). Determining sample size for research activities. Educational and psychological measurement, 30(3), 607-610.

Kuhnert, K. W., \& Lewis, P. (1987). Transactional and transformational leadership: A constructive/developmental analysis. Academy of management review, 12(4), 648-657. doi: https://doi.org/10.5465/amr.1987.4306717

Li, H., Meng, L., Wang, Q., \& Zhou, L.-A. (2008). Political connections, financing and firm performance: Evidence from Chinese private firms. Journal of development economics, 87(2), 283-299. doi: https://doi.org/10.1016/j.jdeveco.2007.03.001

Mesu, J., Sanders, K., \& van Riemsdijk, M. (2015). Transformational leadership and organisational commitment in manufacturing and service small to medium-sized enterprises. Personnel Review.

Miceli, M. P., \& Near, J. P. (1985). Characteristics of organizational climate and perceived wrongdoing associated with whistle-blowing decisions. Personnel psychology, 38(3), 525-544. doi: https://doi.org/10.1111/j.1744-6570.1985.tb00558.x

Nguyen, T. T., Mia, L., Winata, L., \& Chong, V. K. (2017). Effect of transformational-leadership style and management control system on managerial performance. Journal of Business Research, 70, 202-213.

Peterson, R. B. (1975). The interaction of technological process and perceived organizational climate in Norwegian firms. Academy of management Journal, 18(2), 288-299. doi: https://doi.org/10.5465/255531

Piccolo, R. F., \& Colquitt, J. A. (2006). Transformational leadership and job behaviors: The mediating role of core job characteristics. Academy of management Journal, 49(2), 327-340. doi: https://doi.org/10.5465/amj.2006.20786079

Shahin, A., Naftchali, J. S., \& Pool, J. K. (2014). Developing a model for the influence of perceived organizational climate on organizational citizenship behaviour and organizational performance based on balanced score card. International Journal of Productivity and Performance Management. doi: https://doi.org/10.1108/IJPPM-03-2013-0044

Sosik, J. J., \& Godshalk, V. M. (2000). Leadership styles, mentoring functions received, and job-related stress: a conceptual model and preliminary study. Journal of Organizational Behavior, 21(4), 365-390. doi: https://doi.org/10.1002/(SICI)1099-1379(200006)21:4\%3C365::AIDJOB14\%3E3.0.CO;2-H

Taştan, S. B., \& Güçel, C. (2014). Explaining intrapreneurial behaviors of employees with perceived organizational climate and testing the mediating role of organizational identification: A research study among employees of Turkish innovative firms. Procedia-Social and Behavioral Sciences, 150, 862-871. doi: https://doi.org/10.1016/j.sbspro.2014.09.095

Törner, M., Pousette, A., Larsman, P., \& Hemlin, S. (2017). Coping with paradoxical demands through an organizational climate of perceived organizational support: an empirical study among workers in construction and mining industry. The Journal of Applied Behavioral Science, 53(1), 117-141. 